\title{
Effects of the parasitism of Struthanthus flexicaulis (Mart.) Mart. (Loranthaceae) on the fitness of Mimosa calodendron Mart. (Fabaceae), an endemic shrub from rupestrian fields over ironstone outcrops, Minas Gerais State, Brazil
}

\author{
Fabiana Alves Mourão ${ }^{1,2}$, Claudia Maria Jacobi ${ }^{1}$, José Eugênio Côrtes Figueira ${ }^{1}$ and Eugênia Kelly Luciano Batista ${ }^{1}$
}

Received: November 26, 2007. Accepted: December 11, 2008

RESUMO - (Efeitos do parasitismo de Struthanthus flexicaulis (Mart.) Mart. (Loranthaceae) na aptidão de Mimosa calodendron Mart. (Fabaceae), um arbusto endêmico dos campos rupestres sobre canga, em Minas Gerais, Brasil). As plantas parasitas (ervas-de-passarinho) podem alterar o crescimento, reprodução e fisiologia das hospedeiras. Mimosa calodendron (Fabaceae) é uma leguminosa abundante nos campos rupestres sobre canga, freqüentemente atacada pela hemiparasita Struthanthus flexicaulis (Loranthaceae). O objetivo deste trabalho foi avaliar as conseqüências do parasitismo de S. flexicaulis na aptidão de $M$. calodendron. Foram avaliadas a intensidade de parasitismo e mortalidade em mimosas de diferentes tamanhos, e comparadas a cobertura foliar e a produção de frutos e sementes em indivíduos parasitados e não parasitados. Mais de $65 \%$ da população de 1.820 indivíduos estavam parasitados. A densidade de mimosas influenciou positivamente o parasitismo. As taxas de parasitismo e de mortalidade foram maiores nas mimosas de maior porte. As plantas hospedeiras muito parasitadas apresentaram de 75 a $95 \%$ de redução da cobertura foliar e sua produção de frutos foi cerca de $25 \%$ das não parasitadas. Embora não tenha sido detectada diferença estatística no número de sementes produzidas por vagem, o peso das sementes foi menor nas mimosas parasitadas. O parasitismo por S. flexicaulis, por reduzir as taxas de sobrevivência e fecundidade de $M$. calodendron, pode modificar sua estrutura e dinâmica populacional.

Palavras-chave: Canga, Mimosa, parasitismo, sucesso reprodutivo, Struthanthus

ABSTRACT - (Effects of the parasitism of Struthanthus flexicaulis (Mart.) Mart. (Loranthaceae) on the fitness of Mimosa calodendron Mart. (Fabaceae), an endemic shrub from rupestrian fields over ironstone outcrops, Minas Gerais State, Brazil). Parasitic plants (mistletoes) may alter the growth, reproduction and physiology of their hosts. Mimosa calodendron (Fabaceae) is a legume abundant in rupestrian fields on ironstone outcrops, frequently attacked by the hemiparasite Struthanthus flexicaulis (Loranthaceae). The objective of this study was to evaluate the consequences of parasitism by $S$. flexicaulis on the fitness of $M$. calodendron. The intensity of parasitism and mortality on hosts of different sizes was evaluated, and foliage cover, fruit and seed set in parasitized and non-parasitized individuals were compared. More than $65 \%$ of a population of 1820 individuals was attacked. Host density positively influenced parasitism. The mortality and number of attacked hosts increased with their crown diameter. Heavily parasitized individuals showed 75 to $95 \%$ reduction of leaf cover and fruit production of $25 \%$ of those non-parasitized. Although no statistical difference was detected between the number of seeds per fruit, seed weight was lower in attacked plants. Parasitism by S. flexicaulis on M. calodendron may alter its population structure and dynamics, by reducing survival and fecundity rates.

Key words: Ironstone, Mimosa, parasitism, reproductive success, Struthanthus

\section{Introduction}

Mistletoes are parasitic plants which constitute a diverse taxonomic group, the majority of which are dispersed by birds (Press et al. 1999). In Brazil, these plants belong to families Loranthaceae and Santalaceae (Restrepo et al. 2001). Loranthaceae is composed of approximately 1000 species distributed among 75 genera. Thirty-six species belonging to six genera have already been described for the Brazilian cerrado, of which Struthanthus is the most important, with 16 species (Barboza \& Proença 1999). The most common root in Loranthaceae is the haustorium, an epicortical, dilated structure capable of invading the vascular tissue of other species (Riopel \& Timko 1995; Calvin \& Wilson 2006). Many parasitic plants are considered epiparasites, because they grow over the branches of their hosts, and hemiparasites, because they are able to photosynthetize, although they may obtain up to $60 \%$ of the carbohydrates from their hosts (Calder \& Bernardt 1983; Ehleringer et al. 1985).

Through the haustoria, the parasite removes water and nutrients necessary for its survival from the host (Riopel \&
Timko 1995; López de Buen \& Ornelas 2002). When they invade the vascular system of the hosts, parasitic plants may alter their growth, form, reproduction and physiology, besides significantly reducing their performance (Press $e t$ al. 1999; Howell \& Mathiasen 2004). The effects on the allometry and architecture of the hosts may in turn reduce their photosynthetic capacity and respiration rates (Ehleringer et al. 1985). The time since infection is a crucial factor because as the parasite grows it absorbs more minerals and water from their hosts, usually leading to decrease in growth (Howell \& Mathiasen 2004). According to Graves (1995), the effects of parasitism by mistletoes generally depend on four factors: 1) size of the parasite; 2) growth rate and metabolic activity of the parasite; 3) degree of dependence of the resources taken from the hosts, and 4) stage of development of the host. A parasitized host may suffer a reduction in fitness (Press \& Phoenix 2005), defined as the individual contribution to population growth. At the population level, parasitic organisms may control the spread of their hosts, since they affect their reproduction and physiology. In this context, factors that affect fruit

\footnotetext{
1 Universidade Federal de Minas Gerais, Instituto de Ciências Biológicas, Departamento de Biologia Geral, Belo Horizonte, MG, Brasil

2 Corresponding author: fabimourao@gmail.com
} 
production and seed viability are among the most important to be evaluated. Parasitic plants may alter the rates of survival and fecundity of their hosts and hence modify the structure and dynamics of their populations (Press \& Phoenix 2005).

Hosts may show different susceptibility to the attack of parasites (Aukema \& Del Rio 2002), on account of the development stage, age and size. Many hosts react to parasitism by developing defense mechanism (Aukema 2003). These mechanisms include architectural characteristics that obstruct seed deposition, and structural and biochemical, that prevent seedling establishment after the seed is deposited (Reid et al. 1994; Medel 2000). The developmental stage or size of the host may contribute to the differential deposition of mistletoe seeds by the bird disperser, reflecting a pattern of perching preference, and anatomic characteristics interfere in the persistence of the parasite plant through time (Aukema \& Del Rio 2002). Seeds that manage to establish themselves may germinate, form a connection with the host plant and emit haustoria, essential for the establishment and survival of parasite seedlings (Norton \& Carpenter 1998; Roxburgh \& Nilcolson 2005).

The development of mistletoes is dependent on the "quality" of the hosts, that is, on the resources that these may provide for their growth (Press \& Phoenix 2005). It is a known fact that establishment is more probable in more abundant host species (Roxburgh \& Nicolson 2005) and this may be attributed to the easiness of encounters between parasites and hosts (Norton \& De Lange 1999). Furthermore, hosts that are nutritionally rich may favor the survival and reproduction of their parasites (Bowie \& Ward 2004; Kelly 1990), and for this reason nutrient-rich hosts are more parasitized (Kelly 1990).

Mimosa calodendron Mart. (Fabaceae) is a legume endemic to rupestrian fields on ironstone outcrops in the Iron Quadrangle (Quadrilátero Ferrífero, SE Brazil), where it is abundant (Barneby 1991). Its populations are aggregated and conspicuous among other plants in the community, forming green patches in the landscape. Because it is perennial and shrubby, it is used as perch by several birds, including the dispersers of Struthanthus flexicaulis (Mart.) Mart. (Loranthaceae). These birds regurgitate the seeds of $S$. flexicaulis on the branches of $M$. calodendron, promoting the dispersal of the parasite.

Struthanthus flexicaulis (Mart.) Mart. is one of the most common Brazilian hemiparasites, with ample distribution in cerrado areas of central Brazil (Rizzini 1980, 1997). The study by Mourão et al. (2006) confirmed the generalist pattern noted by Norton \& Carpenter (1998) for other tropical Loranthaceae. The fruit of this species contains a single seed associated to a sticky substance, the viscum, which serves to attach the seed to the branches of its hosts. Its branches are long and flagelliform, where appressoria are formed, structures that help fixation of the parasite to its host. The leaves are green, small and oblong-abovate, with maximum length of approximately $3 \mathrm{~cm}$. After fixation of the appressoria, a connection between parasite and host is essential for the penetration of the haustorium into the xylem (Norton \& Carpenter 1998; López de Buen \& Ornelas 2002).

The aim of this study was to evaluate the effect of parasitism of S. flexicaulis on the fitness of a population of M. calodendron, in a rupestrian field over ironstone outcrops. For this, the following questions were posed: 1) Does the density of $M$. calodendron affect the rate of parasitism? 2) Does the size of the host affect its rates of parasitism and mortality? 3) Does parasitism affect the production of fruits and seeds?

\section{Material and methods}

Study area - The study was performed in a region of rupestrian field over ironstone outcrop, a very compact iron-ore substrate with very low erodibility and with varied degrees of porosity and permeability (Klein 2000; Rosière \& Chemale Jr. 2000; Vilela et al. 2004). In these environments, the soil, when it exists, is shallow and nutrient-poor, temperature is high during the day, due to the high incidence of UV rays, and the vegetation is subjected to high winds (Silva et al. 1996; Viana \& Lombardi 2007). The study area is located in the Serra do Rola Moça State Park - MG, southern portion of the Iron Quadrangle $\left(20^{\circ} 03^{\prime} 60^{\prime \prime} \mathrm{S}, 44^{\circ} 02^{\prime} 00^{\prime \prime} \mathrm{W}\right.$, alt. $\left.1380 \mathrm{~m}\right)$. The area is considered of high conservation priority in the state of Minas Gerais, because of its high biological diversity, quantity of endemic species, and strong anthropic pressure (Drummond et al. 2005). The climate in the region is characterized by a pronounced dry season, from April to September (annual mean rainfall 1000 to $1500 \mathrm{~mm}$ ), and annual mean temperature around $25^{\circ} \mathrm{C}$. The vegetation has several morphological and physiological adaptations necessary to its survival, such as coriaceous or succulent leaves, modifications of organs in storing structures, and hairy leaves (Viana \& Lombardi 2007). The plant community has few arboreous individuals, and is dominated by eudicots such as Asteraceae, Fabaceae and Myrtaceae, and monocots such as Poaceae, Cyperaceae and Orchidaceae (Jacobi et al. 2007).

Methods - The focal species M. calodendron was chosen because it is the most abundant and parasitized in the study area. To evaluate if host aggregation assists parasitism, nine 1-m width parallel transects of variable lengths (165 to $375 \mathrm{~m}$ ) were established, crossing the field from end to end. These transects were distant $50 \mathrm{~m}$ from each other and covered an area of approximately 9 ha within a $1.9 \mathrm{~km}$ perimeter. Within these strips, when a focal individual was found a $4 \times 4 \mathrm{~m}^{2}$ plot was delimited, having it as centre. All individuals of $M$. calodendron of height $\geq 30 \mathrm{~cm}$ within the plots were counted. To establish if M. calodendron occurred isolated or in groups, a Poisson distribution was used, comparing the probability of expected occurrence with that observed in the field, and confirmed with a Chi-square test.

To perform population studies and evaluate the effects of parasitism in the fitness of $M$. calodendron, two areas with similar densities of parasite and host (A and B) were selected. Area A was kept intact, whereas fruits of $M$. calodendron were collected in area B. In the former $\left(80 \times 40 \mathrm{~m}^{2}\right)$, we aimed to determine whether parasitism and mortality occurred randomly among hosts of different sizes. In this area, all individuals of $M$. calodendron were numbered. With the aid of a $1 \mathrm{~m}$ ruler, measures of the maximum height and maximum crown diameter were taken. These individuals were also divided into the following categories: parasitized or not, dead or alive, and whether parasitized by bird dispersal (evidenced by the presence of a primary haustorium) or vegetative dispersal (presence of secondary haustoria). Primary haustoria are formed by the connection of the seedling of the parasite with a branch of its host, while secondary haustoria are formed from the contact of a branch of the parasite with one of its host. The hosts were separated in size classes, determined by the crown diameter (that is correlated with height $\mathrm{r}_{\mathrm{s}}=0.732 ; \mathrm{n}=342$; $\mathrm{p}<0.0001)$. No individual with diameter less than $30 \mathrm{~cm}$ was 
parasitized, so this size class was included only in the population structure analysis.

In area $\mathrm{B}$, data on foliage cover and fruit production in both parasitized and non-parasitized were collected, during the rainy season (January through April 2006). To estimate the size of S. flexicaulis within the crown of the hosts, a parasitism index (PI) was calculated. This consisted in tracing parallel transects, distant $10 \mathrm{~cm}$ from each other, over the whole host crown. To account for crown irregularities and standardize measures among individuals, transects initiated $10 \mathrm{~cm}$ from the crown edges (Fig. 1). The number of intersects (ni) between the stems of the parasite and the transects was counted. The total intersects were then divided by the crown area $\left(\mathrm{PI}=\Sigma \mathrm{ni} / \pi \mathrm{r}^{2}\right)$. A Spearman correlation was used to verify if large crowns hosted a larger size (density) of the parasite (ni). Variances were homogenized using a base 2 logarithmic transformation.

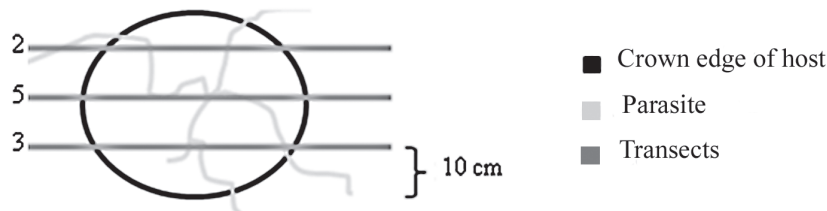

Figure 1. Schematic drawing of the method used to calculate the Parasitism Index PI $=\Sigma$ (ni) / A. Numbers in grey indicate the number of intercepts between branches of the parasite and the transect (ni).

To analyze the effect of $S$. flexicaulis on the leaf cover of M. calodendron, 50 individuals with different levels of parasitism were visually selected, and the maximum crown diameter measured. Also, the leaf cover of each focal individual was estimated using a $10 \times 10 \mathrm{~cm}^{2}$ frame placed over the crown in three positions equidistant from each other. This design minimized the variation in foliage cover in each crown. Each frame was photographed and, with the aid of the Photoshop CS2 image editor, divided into four parts to visually estimate foliage cover. The mistletoe leaf cover, when present, was not taken into account. A mean of the four percentages in each frame was calculated, and then a mean of the three frames in each crown. A Spearman correlation was used to check the relationship between PI and foliage cover. To homogenize variances, data were logtransformed.

To evaluate the effect of parasitism on the host fruit production, 60 individuals ( 30 parasitized and 30 uninfected) were randomly tagged and their crown area was estimated based on diameter measures. In each individual, all fruits within a $300 \mathrm{~cm}^{2}$ quadrat -randomly placed over the crown-were collected. Fruits and seeds of each individual were later counted, and all seeds weighed to estimate the mean weight. A linear regression was used to evaluate the relationship between number of fruits produced and the PI. To homogenize variances and normalize regression residuals, data were log-transformed. A MannWhitney U-test was used to compare the number of fruits produced, since this dataset did not show normal distribution even after mathematical transformations. To compare the number and weight of seeds between parasite-free and parasitized individuals a Student t-test was used. Statistical analyses were based on Zar (1999), using software Systat 8 (Wilkinson 1998).

\section{Results}

Throughout the nine transects, 208 plots of $16 \mathrm{~m}^{2}$ were delimited, totaling 1820 individuals of $M$. calodendron, of which 1209 (66.4\%) were parasitized. The number of individuals of $M$. calodendron sampled per plot ranged from 1 to 37 , with a mean of 8.75 individuals/plot. Only $7.2 \%$ of the plots had one individual, $31.3 \%$ between two and five, and $61.5 \%$ had over six individuals. The aggregated distribution of the species was confirmed $\left(\mathrm{X}^{2}=578.7 ; \mathrm{df}=12\right.$; $\mathrm{p}<0.0001)$. The density of $M$. calodendron individuals positively influenced parasitism. Plots with up to five plants had less than $40 \%$ of them attacked by S. flexicaulis, whereas plots with more than ten individuals had approximately $75 \%$ of individuals parasitized (Tab. 1).

Table 1. Distribution of parasitized individuals of Mimosa calodendron Mart. in density classes (total number of individuals of $M$. calodendron per plot), in $20816 \mathrm{~m}^{2}$ plots.

\begin{tabular}{ccccc}
\hline Density classes Number of & $\begin{array}{c}\text { Number of } \\
\text { plots }\end{array}$ & $\begin{array}{c}\text { \% Parasitized } \\
\text { individuals }\end{array}$ & $\begin{array}{c}\text { Parasitized/plot } \\
\text { imean } \pm \text { SD) }\end{array}$ \\
\hline 1 to 5 & 81 & 243 & 38.7 & $1.2 \pm 1.1$ \\
6 to 10 & 67 & 530 & 60.0 & $4.7 \pm 3.1$ \\
11 to 15 & 30 & 390 & 75.6 & $9.8 \pm 3.4$ \\
16 to 20 & 14 & 249 & 74.7 & $13.3 \pm 4.5$ \\
$>21$ & 16 & 412 & 76.2 & $19.6 \pm 7.0$ \\
\hline
\end{tabular}

The crown diameter of 390 individuals measured in area A varied from 10 to $210 \mathrm{~cm}$. Of these, 44 were dead and, with one exception, all had remnants or live branches of the parasite. Hosts with less than $30 \mathrm{~cm}$ diameter were not parasitized (Fig. 2); above this class size the percentages of parasitized and/or dead individuals increased with crown size $\left(r_{s}=0.933 ; n=158 ; \mathrm{p}<0.001\right)$.

Regarding the type of parasitism, only four individuals were infected by seed deposition (Fig. 3). The percentage of parasitism by secondary haustoria decreased with crown diameter, and the opposite occurred in plants parasitized by both seeds and secondary haustoria $\left(\mathrm{r}_{\mathrm{s}}=0.627 ; \mathrm{n}=50\right.$; $\mathrm{p}<0.0001$; Fig. 4).

In the 50 plants from area B used to evaluate the correlation between loss of foliage cover and level of parasitism, the PI varied from 0.008 to 2.496 intersects $/ \mathrm{cm}^{2}$, whereas the percentage of foliage cover ranged from 7 to 95\% (Fig. 5). Foliage cover decreased with increasing PI $\left(\mathrm{r}_{\mathrm{s}}=-0.508 ; \mathrm{n}=50 ; \mathrm{p}<0.0001\right)$. Highly parasitized plants (PI $>1.5$ intersects $/ \mathrm{cm}^{2}$ ) showed foliage cover of 75 to $95 \%$ less than mistletoe-free plants.

In the 60 plants used to evaluate fruit production, PI values among infected plants ranged from 0.005 to 0.028 intersects $/ \mathrm{cm}^{2}$. Of the mistletoe-free plants, $60 \%$ produced more than 100 fruits $/ 300 \mathrm{~cm}^{2}$ (mean $\left.=144\right)$, whereas the infected group produced a mean of 37 fruits. The difference in fruit production between infected and non-

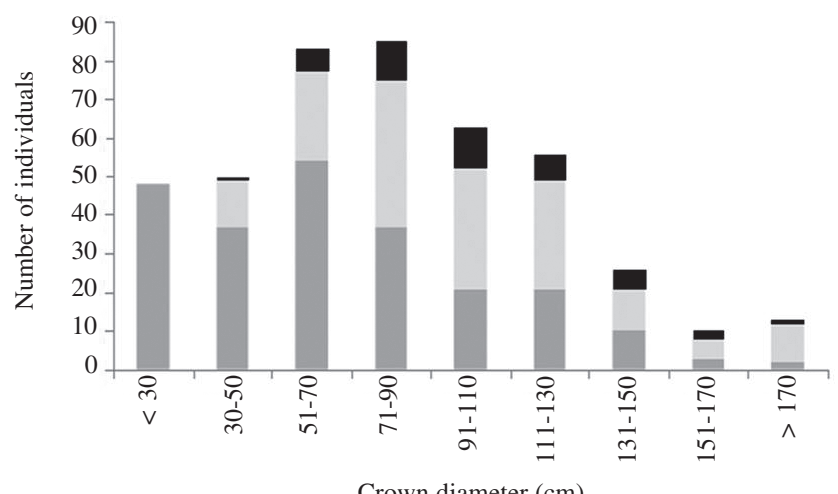

Figure 2. Frequency distribution of parasitized Mimosa calodendron Mart., by size classes. ( $\mathbf{\square}=$ dead; $\square=$ parasitized; $\square=$ not parasitize). 
infected plants was significant $(\mathrm{U}=159.5 ; \mathrm{p}<0.05)$. The number of fruits was negatively correlated with $\mathrm{PI}\left(\mathrm{r}_{\mathrm{s}}=-0.700\right.$; $\mathrm{n}=60 ; \mathrm{p}<0.0001 ;$ Fig. 6). In the 30 infected individuals a total of 880 seeds were counted, compared to 1365 in the 30 parasite-free individuals. The number of seeds per fruit in non-infected individuals varied from zero to five and, among those infected, from zero to four, most of which containing two seeds. The Student t-test did not detect significant differences in seed set. Seeds of non-infected individuals weighed $0.012 \mathrm{~g} \pm 0.003$, whereas seeds produced by infected individuals were significantly lighter $(0.010 \mathrm{~g} \pm 0.010$; $\mathrm{t}=3.06 ; \mathrm{n}=30 ; \mathrm{p}<0.002$ ).

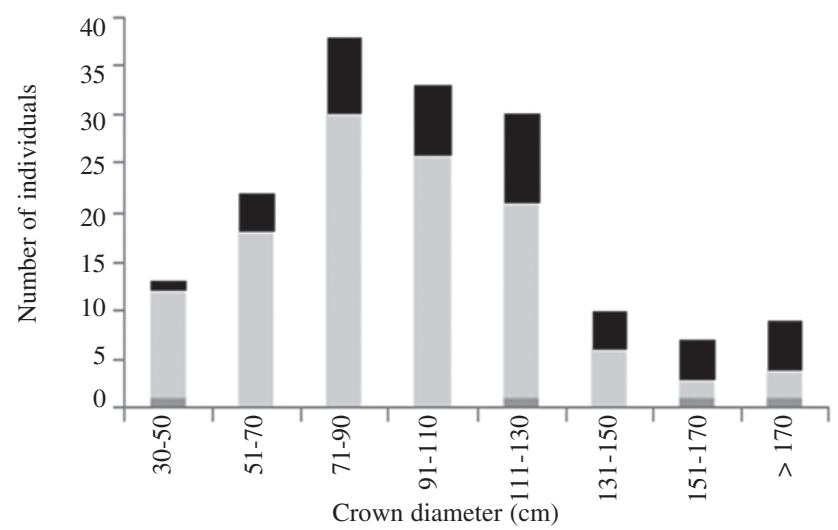

Figure 3. Frequency distribution of parasitism types in individuals of Mimosa calodendron Mart. ( $\mathbf{\square}=$ both; $\square=$ secondary haustoria; $\square=$ seeds $)$.

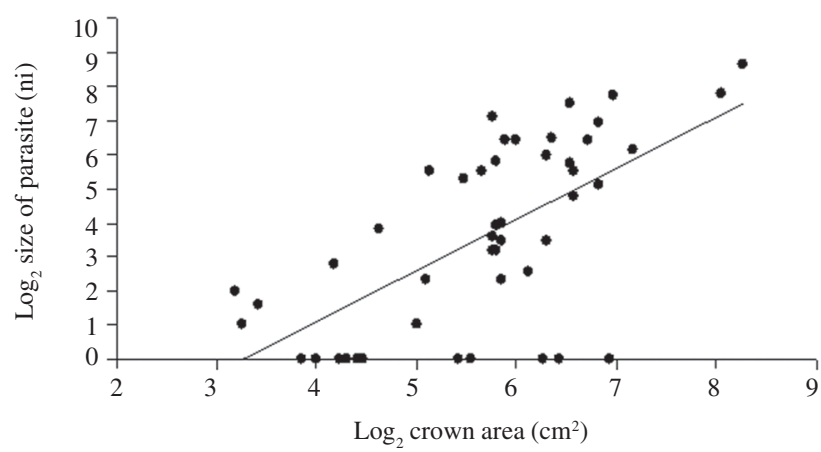

Figure 4. Correlation between crown area of Mimosa calodendron Mart. individuals and parasite size (ni) $\left(r_{s}=0.507 ; n=47 ; p<0.0001\right)$.

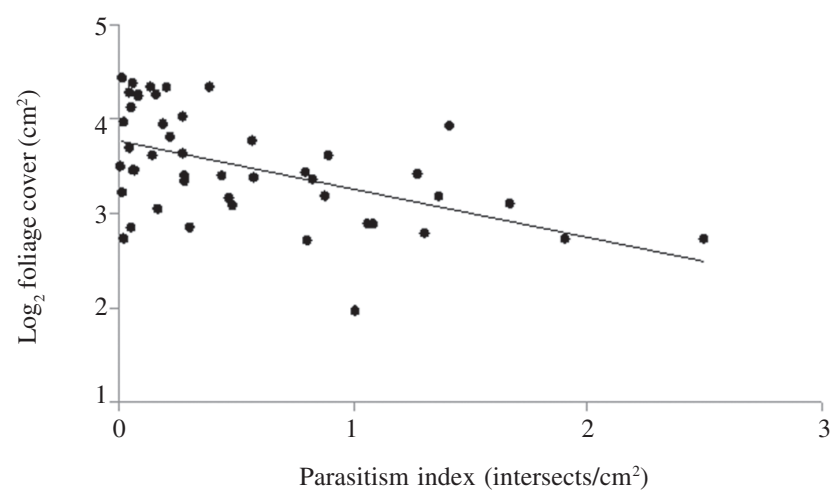

Figure 5. Correlation between the Parasitism Index PI and foliage cover of Mimosa calodendron Mart. $\left(\mathrm{r}_{\mathrm{s}}=-0.508 ; \mathrm{n}=47 ; \mathrm{p}<0.0001\right)$.

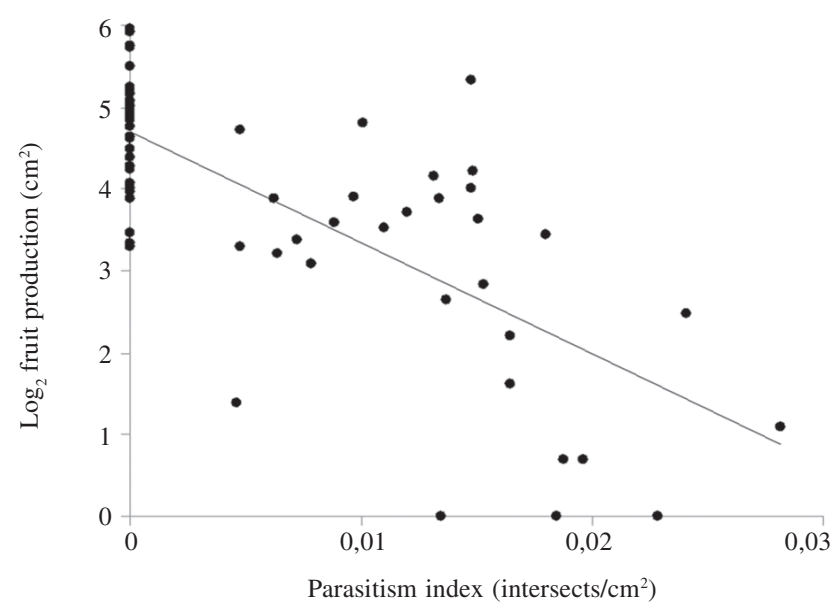

Figure 6. Correlation between Parasitism Index PI and fruit production in Mimosa calodendron Mart. $\left(\mathrm{y}=4.671-112.7 \mathrm{x} ; \mathrm{n}=57 ; \mathrm{r}^{2}=0.465 ; \mathrm{p}<0.0001\right)$.

\section{Discussion}

The majority of studies with parasitic plants have concentrated on ornithochoric dispersal of arboreal mistletoes (ex. Overton 1994; Arruda et al. 2006; Spurrier \& Smith 2007). This interaction is fundamental for the dispersal of the parasite in open physiognomies, in which the crown of trees and shrubs are far apart. In this case, the spread of mistletoe branches from one crown to another is highly improbable. On the other hand, in more dense physiognomies, vegetative dispersal becomes as important as, or even more important than, seed dispersal by birds, because the many branches of the parasite are capable of reaching neighbor crowns. This is the case in the rupestrian field studied, where $M$. calodendron has aggregated distribution and the individuals are very close to each other, enhancing the spread of $S$. flexicaulis branches to new hosts.

The vegetative dispersal of $S$. flexicaulis, together with lack of host specificity (Mourão et al. 2006), may grant the encounter with other hosts. The large crown size and aggregated distribution of $M$. calodendron would also enhance its location by the mistletoe bird disperser, increasing the chances of $S$. flexicaulis seed deposition (see also Aukema \& Del Rio 2002). According to Overton (1994), a longer time of dispersers on host crowns, when parasites are in the reproductive stage, and ornithochoric dispersal, which occurs frequently in individuals close to each other, result in high rates of reinfection, enhancing parasite aggregation, mainly when hosts are close to each other. Corroborating the findings of other authors (Overton 1994; Norton et al. 1995; Lei 1999; Aukema \& Del Rio 2002), higher rates of infection were also found in larger M. calodendron individuals. This could be explained by the higher chances of these hosts being both more easily reached by branches of $S$. flexicaulis coming from neighbor plants and visited by disperser birds. An alternative hypothesis for the positive association between crown size and infection rate is that larger, supposedly older hosts, 
were exposed for longer periods to parasite infection. However, specific studies are needed to substantiate these ideas.

Kelly (1990) stated that reproduction and survival of hosts depend on the size of the parasite. In order to grow and invest in reproductive structures, $S$. flexicaulis taps water and nutrients from its hosts, limiting the resources that these would use for their own growth, reproduction and survival. In $M$. calodendron this is evidenced by the increasing loss of foliage cover with parasite size. Reduction in reproductive investments is an expected consequence of photosynthetic area loss (Crawley 1997), as demonstrated in a defoliation experiment of the shrub Piper arieianum (Piperaceae) (Marquis 1992). In infected M. calodendron, loss of leaf area was correlated with reduction of fruit number and also seed weight, which could affect the survival of seedlings after germination. In extreme cases, $S$. flexicaulis infestation can cause the death of $M$. calodendron, as indicated by the high proportion of dead M. calodendron still bearing live parasites or their vestiges. Although static data should be interpreted with caution, the mortality rate found here was higher in parasitized plants. This high rate could be a direct consequence of a long term deviation of host resources to S. flexicaulis, allied to the severe edapho-climatic conditions of ironstone outcrops, magnifying the hydric stress upon the host. If so, mortality rates of $M$. calodendron would possibly increase in the dry period, when water scarcity is critical.

Parasitism by $S$. flexicaulis may drastically alter the population structure and dynamics of $M$. calodendron, one of its many hosts in rupestrian field on ironstone outcrops (Mourão et al. 2006). The negative effects of the parasite may occur in cascade, because an accentuated parasitism may lead, prior to host death, to loss of foliage cover and indirectly reduce photosynthetic rates. This, together with decreased fruit and seed sets, probably reduces recruitment rates of new individuals.

Mimosa calodendron is one of the most abundant and large plants in the Iron Quadrangle rupestrian fields and contributes to nitrogen enrichment of its nutrient-poor soil. Its dense crowns help reduce the high temperature on ironstone and add significantly to soil formation, through the incorporation of organic matter (Jacobi et al. 2007). In addition, because of their attractiveness to frugivorous birds, individuals act as infection foci of $S$. flexicaulis. Thus, it is possible to predict that high levels of parasitism will interfere in the population dynamics of $M$. calodendron and, indirectly, alter the population structure and dynamics of other plant species of the community throughout time.

\section{Acknowledgements}

We thank Marcos Sobral, Pedro L. Viana, Rubens C. Mota and Gustavo Heringer for identification of plant species, Flavio Fonseca do Carmo for field assistance, IEF/MG (Minas Gerais Forest Institute) for collection permit 014/05, the staff of Serra do Rola Moça State Park for logistic support, FAPEMIG (Minas Gerais Research Funding Agency, grant CRA 89/04), and US Fish and Wildlife Service for financial support. We also thank two anonymous reviewers for their valuable suggestions. This work is part of the MSc. thesis of the first author, Graduate Program in Ecology, Conservation and Management of Wildlife, Federal University of Minas Gerais.

\section{References}

Arruda, R.; Carvalho, L.N. \& Del-Claro, K. 2006. Host specificity of a Brazilian mistletoe, Struthanthus aff. polyanthus (Loranthaceae), in cerrado tropical savanna. Flora 201: 127-134.

Aukema, J.E. 2003. Vectors, viscin, and Viscaceae: mistletoes as parasites, mutualists and resources. Frontiers in Ecology and the Environment 1: 212-219.

Aukema, J.E. \& Del Rio, C.M. 2002. Where does a fruit-eating bird deposit mistletoe seeds? Seed deposition patterns and an experiment. Ecology 83: 3489-3496.

Barboza, M.A. \& Proença, C.E.B. 1999. Loranthaceae no bioma cerrado. Pp. 243-244. In: Anais do 50 ${ }^{\circ}$ Congresso Nacional de Botânica. Blumenau, 1999. Santa Catarina.

Barneby, R.C. 1991. Sensitivae censitae: a description of the genus Mimosa Linnaeus (Mimosaceae) in the New World. New York, The New York Botanical Gardens.

Bowie, M. \& Ward, D. 2004. Water and nutrient status of the mistletoe Plicosepalus acaciae parasitic on isolated Negev Desert populations of Acacia radiana differing in level of mortality. Journal of Arid Environments 56: 487-508.

Calder, M. \& Bernardt, P. 1983. The biology of mistletoes. Sidney, Academic.

Calvin, C.L. \& Wilson, C.A. 2006. Comparative morphology of epicortical roots in Old and New World Loranthaceae with reference to root types, origin, patterns of longitudinal extension and potential for clonal growth. Flora 201: 345-353.

Crawley, M.J. 1997. Plant Ecology. Oxford, Blackwell Scientific.

Drummond, G.M.; Martins, C.S.; Machado, A.B.M.; Sebaio, F.A. \& Antonini, Y. (orgs.). 2005. Biodiversidade em Minas Gerais - Um Atlas para Sua Conservação. Belo Horizonte, Fundação Biodiversitas.

Ehleringer, J.R.; Schulze, E.D.; Ziegler, H.; Lange, O.L.; Farquhar, G.D. \& Cowar, I.R. 1985. Xylem-tapping mistletoes: water or nutrient parasites? Science 227: 1479-1481.

Graves, J.D. 1995. Host-plant responses to parasitism. Pp. 23-49. In: M.C. Press \& J.D. Graves (eds.). Parasitic plants. London, Chapman \& Hall.

Howell, B.E. \& Mathiasen, R.L. 2004. Growth impacts of Psittacanthus angustifolius Kuijt on Pinus oocarpa Schiede in Honduras. Forest Ecology and Management 198: 75-88.

Jacobi, C.M.; Carmo, F.F.; Vincent, R.C. \& Stehmann, J.R. 2007. Plant communities on ironstones outcrops: a diverse and endangered Brazilian ecosystem. Biodiversity and Conservation 16: 2185-2200.

Kelly, K.C. 1990. Plant foraging: a marginal value model and coiling response in Cuscuta subinclusa. Ecology 71: 1916-1925.

Klein, C. 2000. Geochemistry and petrology of some Proterozoic banded iron-formations of the Quadrilátero Ferrífero, Minas Gerais, Brazil. Economic Geology 95: 405-428.

Lei, S.A. 1999. Age, size and water status of Acacia gregii influencing the infection and reproductive success of Phoradendron californicum. American Midland Naturalist 141: 358-365.

López de Buen, L.E. \& Ornelas, J.F. 2002. Host compatibility of cloud forest mistletoe Psittacanthus schiedeanus, in central Veracruz, Mexico. American Journal Botany 89: 95-102.

Marquis, R.J. 1992. A bite is a bite is a bite? Constraints on response to folivory in Piper arieianum (Piperaceae) Ecology 75: 143-152. 
Medel, R. 2000. Assessment of parasite-mediated selection in a hostparasite system in plants. Ecology 81: 1554-1564.

Mourão, F.A.; Carmo, F.F.; Ratton, P. \& Jacobi, C.M. 2006. Hospedeiras da hemiparasita Struthanthus flexicaulis (Mart.) Mart. (Loranthaceae) em campos rupestres ferruginosos do Quadrilátero Ferrífero, Minas Gerais. Lundiana 7: 103-109.

Norton, D.A. \& Carpenter, M.A. 1998. Mistletoes as parasites: host specificity and speciation. Trends in Ecology and Evolution 13: 101-105.

Norton, D.A. \& De Lange, P.J. 1999 Host specificity in parasitic mistletoes (Loranthaceae) in New Zealand. Functional Ecology, 13: $552-559$.

Norton, D.A.; Hobbs, R.J. \& Atkins, L. 1995. Fragmentation, disturbance and plant distribution: mistletoes in woodland remnants in the Western Australia wheatbelt. Conservation Biology 11: 759-769.

Overton, J.M. 1994. Dispersal and infection in mistletoe metapopulations. Journal of Ecology 82: 711-723.

Press M.C.; Scholes, J.D. \& Watling, J.R. 1999. Parasitic plants: physiological e ecological interactions whit their hosts. Pp. 175-197. In: M.C. Press; J.D. Scholes \& M.G. Barker (eds.). Physiological plant Ecology. Oxford, Blackwell Scientific.

Press, M.C. \& Phoenix, G.K. 2005. Impacts of parasitic plants on natural communities. New Phytologist 166: 737-751.

Reid, N.; Yan, Z. \& Fittler, J. 1994. Impact of mistletoes (Amyema miquelii) on host (Eucalyptus blakelyi and Eucalyptus melliodora) survival and growth in temperate Australia. Forest Ecology and Management 70: 55-65.

Restrepo, C.; Sargent, S.; Levey, D.J. \& Watson, D.M. 2001. The role of vertebrates in the diversification of New World mistletoes. Pp. 23-52. In: D.J. Levey; W.R. Silva \& M. Galetti Oxfordshire (eds.). Seed Dispersal and Frugivory: Ecology Evolution and Conservation. Campinas, Cabi.
Riopel, J.L. \& Timko, M.P. 1995. Haustorial initiation and differentiation. Pp. 39-73. In: M.C. Press \& J.D. Graves (eds.). Parasitic plants. London, Chapman \& Hall.

Rizzini, C.T. 1980. Loranthaceae of the central Brazil. Arquivos do Jardim Botânico do Rio de Janeiro 24: 19-50.

Rizzini, C.T. 1997. Tratado de Fitogeografia do Brasil: Aspectos Ecológicos, Sociológicos e Florísticos. Rio de Janeiro, Âmbito Cultural Edições Ltda.

Rosière, C.A. \& Chemale Jr., F. 2000. Brazilian iron formations and their geological setting. Revista Brasileira de Geociências 30: $274-278$.

Roxburgh, L. \& Nicolson, S.W. 2005. Patterns of host use in two African mistletoes: the importance of mistletoe-host compatibility and avian disperser behaviour. Functional Ecology 19: $865-873$.

Spurrier, S. \& Smith, K.G. 2007. Desert mistletoe (Phoradendron californicum) infestation correlates with blue palo verde (Cercidium floridum) mortality during a severe drought in the Mojave desert. Journal of Arid Environments 69: 189-197.

Silva, M.F.F.; Secco, R.S. \& Lobo, M.G.A. 1996. Aspectos ecológicos da vegetação rupestre da serra dos Carajás, estado do Pará, Brasil. Acta Amazonica 26: 17-44.

Viana, P.L. \& Lombardi, J.A. 2007. Florística e caracterização dos campos rupestres sobre a canga na Serra da Calçada, Minas Gerais, Brasil. Rodriguésia 58: 159-177.

Vilela, R.A.; Melo, R.J.; Costa, T.A.V.; Lagoeiro, L.E. \& Varajão, C.A.C. 2004. Petrografia do minério hematita compacta da Mina do Tamanduá (Quadrilátero Ferrífero, MG). Escola de Minas de Ouro Preto 57: 157-164.

Wilkinson L. 1998. Systat 8. The System for Statistics. Evanston, SPSS Inc.

Zar, J.H. 1999. Biostatistical Analysis. New York, Prentice-Hall. 